\title{
MHC Polymorphism and Tuberculosis Disease
}

\author{
Khalid Sadki, Youssef Bakri, M'Hamed Tijane and Saaid Amzazi \\ University Mohammed V-Agdal, Faculty of Sciences, \\ Laboratory of Biochemistry and Immunology \\ Morocco
}

\section{Introduction}

Mycobacterium tuberculosis (Mtb), the causal agent of tuberculosis (TB), remains a major public health throughout the world causing high mortality in humans. According to the report published by the World Health Organization in 2009, 9.3 million new cases of TB were declared in the world and 1.3 million HIV-negative people died by this infection (http://www.who.int/tb/publications/global_report/2010/en/index.html). One-third of the world's population is estimated to be infected with Mtb, but, only 1 in 10 subjects who become infected would develop clinical disease. Furthermore, until now it is not fully understood why this category of individuals develop different forms of TB, pulmonary and extra pulmonary TB. Several environmental factors principally malnutrition, HIV infection and a decrease of socio-economic level favours TB progression. Furthermore, it has been confirmed by numerous studies that the outcome of TB infection is under the influence of the host genetic background (Vannberg et al., 2011). In fact, twin studies have revealed the increased concordance of disease in monozygotic compared with dizygotic twins (Jepson et al., 2001; Maartens et al., 2007). In addition, numerous families and case-control studies have demonstrated the involvement of many genes in the control of immune response in the context of the susceptibility or resistance to TB. Among these genes Major Histocompatibility Complex (MHC) takes a substantial and central role in the control of TB infection (Kamath et al., 2004).

MHC is a genetic complex that encodes the antigen-presenting molecules and is involved in the recognition and cellular cooperation functions which the substratum is the Tymphocyte. Its principal function is to ensure the selection, the transport and the presentation of peptides generated in the antigen-presenting cells. MHC is characterized by an extensive polymorphism. There are currently 6810 HLA alleles described by the HLA nomenclature and integrated in the IMGT/HLA Database (http://www.ebi.ac.uk/imgt/hla/stats.html). This particularity allows to this genetic complex a strong impact in term of immune response efficiency. While some MHC variant genes play a role in the protection against TB others variants in contrast were considered as markers of susceptibility to TB. MHC is the first molecule tested for genetic associations with TB susceptibility. For more than four decades, several authors have described strong associations between some MHC specificities and several immunological disorder including infectious diseases such as TB infection (Yee, 2004; Hill, 2006). The tri-molecular complex of T cell receptor (TCR), antigenic peptide, and 
MHC molecules represents the fundamental basis of the immune response. So, genetic variation that could occur in any genes which code one of these elements could have an impact on the functional levels. MHC system takes a great part of its responsibility in term of TB pathogenesis. For example, the impact of MHC class I alleles on the Mtb antigenspecific CD8+ T-cell response in patients with $\mathrm{TB}$ has been reported by several studies (weichold et al., 2007; Lewinsohn et al., 2007; Smith \& Dockrell, 2000). In addition, according to the MHC class I specificity some important specific peptides selected from Mtb antigens as $\mathrm{Ag} 85 \mathrm{~B}$ and $19-\mathrm{kDa}$ lipoprotein are identified to be recognized by CD8 positive $\mathrm{T}$ lymphocytes (Geluk et al., 2000; Lalvani et al., 1998; Mohagheghpour et al., 1998). These CD8 T cells subset has been suggested to control MTB infection.

The predictive value of MHC system takes a considerable importance concerning susceptibility or resistance to TB disease. Two situations are observed: First, certain MHC markers are positively associated with disease and thus they are considered as markers of susceptibility. Second, other MHC specificities are negatively associated and may have a role in the protection against $\mathrm{TB}$.

In this context, MHC polymorphism has been also employed to identify the efficient peptide that can be used to improve sensitivity and specificity of diagnosis test of TB and vaccine development. On the basis of the prediction of Mtb antigen sequences that bind to MHC molecules, several authors have designed MHC-promiscuous T-cell multi-epitopic peptides (Seghrouchni et al., 2009; Zhang et al., 2010).

The present chapter will discuss the most important work relating, first the impact of MHC polymorphism in the outcome of TB infection, and in the second the improvement of diagnosis method of $\mathrm{TB}$ using reverse immunogenetic.

\section{Major Histocompatibility Complex (MHC) Human Leukocyte Antigen (HLA)}

Major Histocompatibility Complex (MHC) or Human Leukocyte Antigen (HLA) in human coding region is located on the short arm of chromosome 6 (6p21.3). It occupies a segment of about $4000 \mathrm{~kb}$, containing over 220 identified genes (Robinson J et al., 2003). The strong proximity between HLA genes explains why we observe a low rate of genetic recombination within this region. Consequently, HLA genes are transmitted as haplotypes from parents to children. Each individual inherits two parental haplotypes which expression is codominant. The HLA system is divided into three regions (Figure 1)

- From the centromere, there is HLA class II region (about $900 \mathrm{~kb}$ ) which includes at least 32 genes. The most functional histocompatibility genes are represented by HLA-DR, HLA-DQ and HLA-DP. Other genes as large multifunctional protease (LMP2 and LMP7) or Transporter associated with antigen processing (TAP1 and TAP2) are found in this region which play a crucial role, respectively, during antigen processing or in the active transport of peptides across the membrane of the endoplasmic reticulum.

- $\quad$ The intermediate region is HLA class III (about $1100 \mathrm{~kb}$ ) and is composed of at least 39 genes. Among them there are tumor necrosis factor (TNF), complement components (C4A, C4B, BF, and C2), etc.

- The telomeric region covers HLA class I genes and spans $1600 \mathrm{~kb}$. This area contains about 17 genes and is divided into two sub-classes: 
HLA classical class I genes (class Ia) namely HLA-A, HLA-B and HLA-C and HLA nonclassical class I (class Ib) namely HLA-E, HLA-F, HLA-G, Major Histocompatibility Complex class I chain-related A and B (MICA and MICB), etc. (Figure 1). In this region, there is others non histocompatibility genes as UNHCR ( $\alpha$-helix coiled coil rod homolog), and hemochromatosis gene (HEF).

HLA class I genes are composed of eight exons and seven introns. Exon 1 encodes the signal sequence, exons $2,3,4$ respectively encode for the extracellular domain $(\alpha 1, \alpha 2, \alpha 3)$, exon 5 encodes the transmembrane portion and exons $6,7,8$ encode the intra-cytoplasmic (Malissen et al., 1982). HLA class Ia genes are among the most polymorphic genes described in the human genome. According to the IMGT/HLA data base, 1698 alleles of HLA-A, 2271 alleles of HLA-B and 1213 alleles of HLA-Cw have been identified to date. This genetic characterization allows HLA molecule to bind a large repertoire of peptides, controlling $\mathrm{T}$ cell polarization and consequently the profile of the cytokines production. In contrast, this characteristic could subverted if the immune system is disturbed as observed in the autoimmune and also in some infectious diseases development (De Castro, 2009; Acharya et al., 2010).

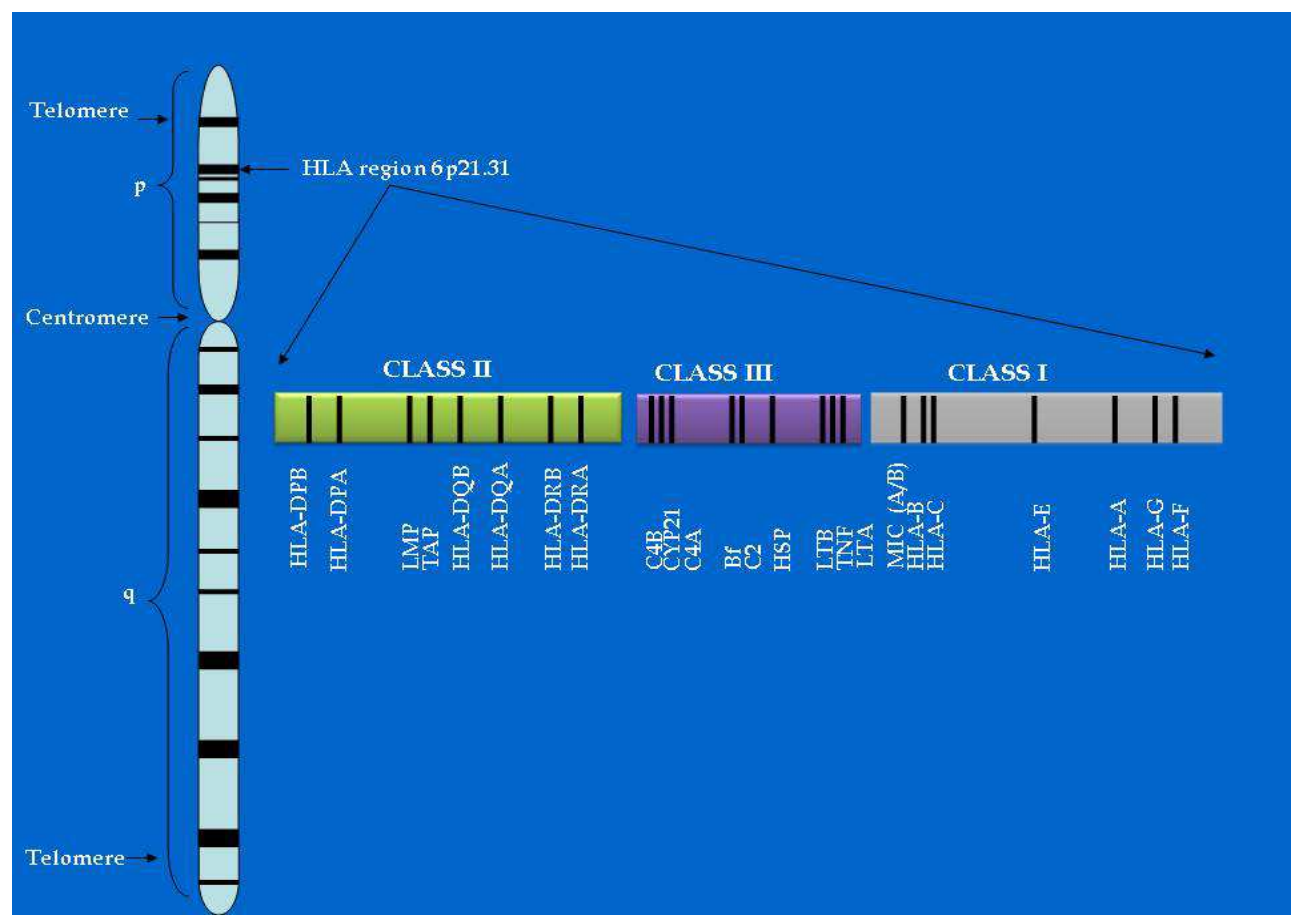

Fig. 1. Genomic organization of Major Histocompatibility Complex region.

At phenotypic level, HLA class I is represented by two chains: alpha heavy chain ( $\alpha$ ) and Beta 2-microglobulin $(\beta 2 \mathrm{~m})$ light chain, and the interaction between a1 and a2 domains generates a peptide binding cleft (figure 2). HLA class I molecule contains a series of six pockets, designated from $\mathrm{A}$ to $\mathrm{F}$ which can establish different interactions with antigenic 
peptide residues (Bjorkman et al. 1987; Garrett et al., 1989). The conserved residues in pockets $\mathrm{A}$ and $\mathrm{F}$ are located at each side of the cavity and are responsible for the orientation of the binding peptide during antigen presentation step, while polymorphic residues located in the pockets B, C, D and E influence the specificity of peptide binding or site of peptide conformation within the cavity (Garrett et al., 1989; Madden et al., 1991; Matsumura et al., 1992).

Concerning HLA class II genes, HLA-DRB1 and HLA-DP1 encompass six exons whereas HLA-DQB1 includes five exons. HLA-DRB1 is the most polymorphic gene within HLA class II. HLA class II molecule consists of two polypeptides chains, alpha (a) and Beta chain (figure 2). Each chain includes two domains a1 and $\alpha 2$ for alpha chain, and $\beta 1$ and $\beta 2$ for $\beta$ chain. The contact established between a1 and $\beta 1$ domains creates the peptide binding site, which interact with TCR. These two domains play an important role during the presentation of antigenic peptide. Moreover, in this region where many genetics variations genetic variation are found, which characterize each HLA class II alleles thereby are influencing the outcome of the immune response.
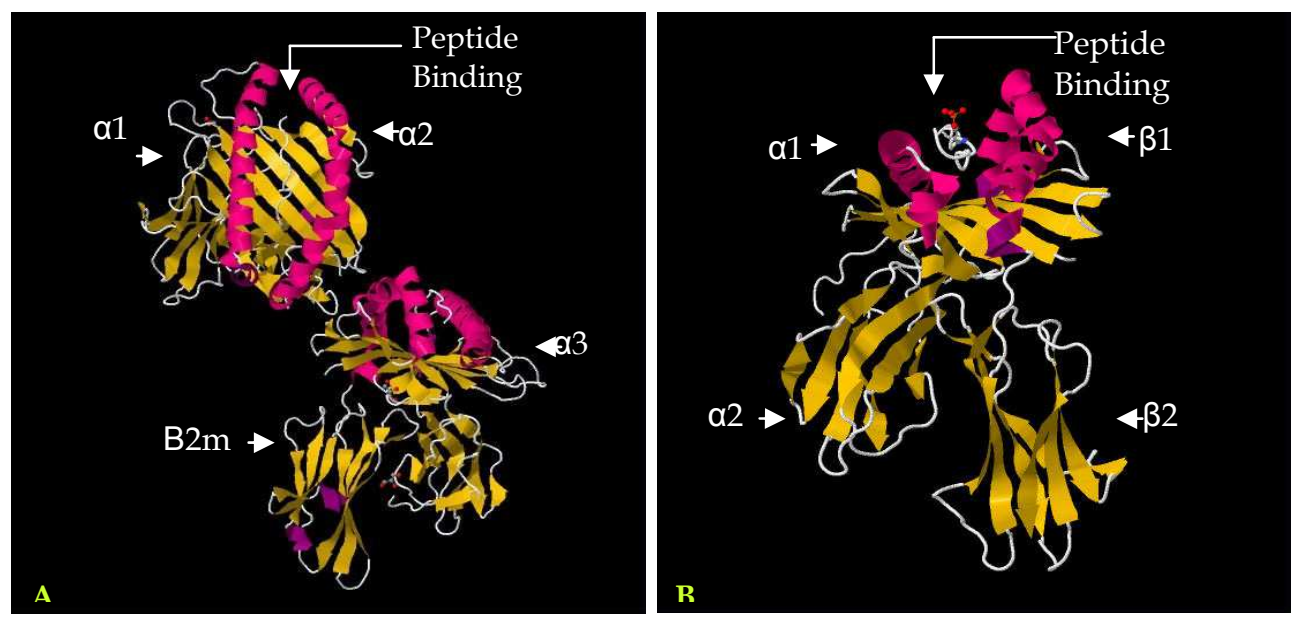

Fig. 2. Crystal structure of MHC class I (A) and class II (B) molecules in complex with antigenic peptide. (Accession numbers taking from Protein Data Bank are respectively 3PWJ and 3L6F) (Borbulevych et al., 2011; Li et al., 2010) (A) : HLA class I is comprised by two chains, alpha heavy chain $(\alpha)$ and Beta 2-microglobulin $(\beta 2 \mathrm{~m})$ light chain, with noncovalent interaction between them. The peptide binding groove shapes a short cleft by an interaction between a1 and a2 domains. (B): HLA class II molecule consists of two polypeptides chains, alpha and Beta chain. Each chain includes two domains a1 and a2 for alpha chain and $\beta 1$ and $\beta 2$ for $\beta$ chain. The interaction between $\alpha 1$ and $\beta 2$ domains generates long peptide binding clefts which interact with TCR.

HLA molecules expression is different between the two classes. In fact, HLA class I molecules are expressed on most mononuclear cells, whereas class II molecules are expressed on antigen presenting cells (APCs): macrophages / monocytes, dendritic cells and $\mathrm{B}$ cells. Moreover, into the same class, different loci do not have the same level of tissue expression, such as HLA-C are naturally more weakly expressed than HLA-A or HLA-B. 


\section{MHC polymorphism and TB disease}

One of the main roles of MHC is to regulate the immune response against all immunological abnormalities in normal physiological condition and during infection state. MHC is known as one of the important component of susceptibility and resistance to many infectious diseases and responsiveness to pathogens or vaccines. In the case of pulmonary TB (PTB) disease, case-control association studies have found significant associations between MHC genes polymorphism and this pathology (Kettaneh et al., 2006; Yim \& Selvaraj, 2010). In fact, both genes encoding MHC class I and class II may play crucial roles in host susceptibility to PTB. table 1 summarizes the most important immunogenetic association studies related to MHC and PTB. Analysis of this table shows that first, the majors susceptibility locus are more within MHC class II region compared to those located in MHC class I section. Indeed, for MHC class I, almost all genetic association with TB are positive. In contrast, both negative and positive association are observed between $\mathrm{TB}$ and MHC class II polymorphism, suggesting a strong influence of MHC class II in the modulation of the immune response to MTB infection through cell-mediated immunity (Moss \& Khanna, 1999; Kettaneh et al., 2006; Yim \& Selvaraj , 2010).

However, the results are conflicting as reported by several studies. MHC polymorphism investigations have revealed, that the allele HLA-DRB1*04 is associated with TB in Syrian population (Harfouch-Hammoud \& Daher, 2008), HLA-DRB1*07 and HLA-DQA1*0101 in Iranians (Amirzargar et al., 2004), HLA-DRB1*11 in Indonesians (Yuliwulandari et al., 2010), and HLA-DRB1*1302 in South Africans (Lombard et al., 2006). HLA-DRB1*0803 and HLADQB1*0601 were associated with PTB disease advancement in Koreans while a strong association with resistance to recurrent PTB is observed (Kim et al., 2005, Yuliwulandari et al., 2010) with HLA-DRB1*12 in Indonesians (Yuliwulandari et al., 2010). Finally, HLA-DR2 seems to be the main allele positively associated with PTB. This observation is replicated in populations with different genetic background, Indian (Brahmajothi et al., 1991, Ravikumar et al., 1999, Sriram et al., 2001), Chinese (Shi et al., 2011) and polish (Dubaniewicz et al., 2000). HLA-DR2 is divided into two subtypes, DRB1*15 and DRB*16. Except for the study reported by Dubaniewicz and his colleagues, DRB1*15, especially the DRB1*1501 allele, is strongly associated with PTB susceptibility (Dubaniewicz et al., 2000). This observation suggests that amino acids present in DR15 molecule but absent in DR16 could play an important role in the development of PTB. Certainly, this data does not exclude the involvement of other region parts of the protein and/or other immunoregulatory linked genes. The nucleotide sequence of the peptide presented by DRB1*15 are so different from those presented by DRB1* 16 and may be recognized by $\mathrm{CD} 4^{+} \mathrm{T}$ lymphocytes as inadequate form and consequently this situation could disturb the effective immune anti-TB response. At functional level, it has been suggested that HLA-DRB1*1501 and HLA-DRB1*1502 may be associated with down-regulation of perforin-positive cytotoxic cells (T-lymphocytes and natural killer) in PTB, supporting the potential role of theses alleles in the TB susceptibility (Rajeswari et al., 2007). On the other hand, HLA-DRB1*16 but not HLA-DRB1*15 are observed more frequently in Brazilian leprosy patients than in controls group $(9.0 \%$ vs. $1.8 \%$; $P=0.0016 ; \mathrm{OR}=5.81 ; \mathrm{CI}=2.05-16.46)$, underlying a difference in the impact of $\mathrm{MHC}$ polymorphism which may be related to the specificity of each pathology (Da silva et al., 2009). 


\begin{tabular}{|c|c|c|c|c|c|c|c|}
\hline \multirow[t]{2}{*}{ Candidate allele } & \multicolumn{3}{|c|}{$\begin{array}{l}\text { Genetic polymorphisms } \\
\text { association }\end{array}$} & \multirow[t]{2}{*}{ Population } & \multirow{2}{*}{$\mathrm{P}$-value } & \multirow{2}{*}{ OR } & \multirow[t]{2}{*}{ References } \\
\hline & Positive & Negative & $\begin{array}{c}\text { Recurrent } \\
\text { disease }\end{array}$ & & & & \\
\hline \multicolumn{8}{|l|}{ HLA class I } \\
\hline A1 & & $X$ & & Indian & $<0.001$ & ND & $\begin{array}{l}\text { (Balamurugan } \\
\text { et al., 2004) }\end{array}$ \\
\hline $\mathrm{B}^{*} 1802$ & & & $\mathrm{X}$ & Indonesian & 0,013 & ND & $\begin{array}{l}\text { (Yuliwulandari } \\
\text { et al., 2010) }\end{array}$ \\
\hline B*4001 & & & $\mathrm{X}$ & Indonesian & 0,015 & ND & $\begin{array}{l}\text { (Yuliwulandari } \\
\text { et al., 2010) }\end{array}$ \\
\hline B51 & $X$ & & & Indian & $<0.0001$ & 0.0 & $\begin{array}{l}\text { (Vijaya Lakshm } \\
\text { et al., 2006) }\end{array}$ \\
\hline B52 & & $X$ & & Indian & $<0.0001$ & 18.53 & $\begin{array}{l}\text { (Vijaya Lakshm } \\
\text { et al., 2006) }\end{array}$ \\
\hline Cw6 & & $X$ & & Indian & $<0.001$ & ND & $\begin{array}{l}\text { (Balamurugan } \\
\text { et al., 2004) }\end{array}$ \\
\hline Cw7 & $X$ & & & Indian & $<0.001$ & ND & $\begin{array}{l}\text { (Balamurugan } \\
\text { et al., 2004) }\end{array}$ \\
\hline \multicolumn{8}{|l|}{ HLA class II } \\
\hline$\overline{D R} 2$ & $x$ & & & Indian & 0,01 & 0.29 & $\begin{array}{l}\text { (Brahmajothi } \\
\text { et al., 1991) }\end{array}$ \\
\hline DRB1*1501 & $\mathrm{X}$ & & & Indian & 0.013 & 2.68 & $\begin{array}{l}\text { (Ravi kumar } \\
\text { et al., 1999) }\end{array}$ \\
\hline DRB1*15 & $X$ & & & Chinese & 0,001 & 3.79 & (Shi et al., 2011) \\
\hline DRB1*16 & $x$ & & & Polish & $<0.01$ & 9.7 & $\begin{array}{l}\text { (Dubaniewicz } \\
\text { et al., 2000) }\end{array}$ \\
\hline DQB1*0301-*0304 & $x$ & & & $\begin{array}{l}\text { South } \\
\text { Africa }\end{array}$ & 0,001 & 2.58 & $\begin{array}{l}\text { (Lombard } \\
\text { et al., 2006) }\end{array}$ \\
\hline DRB1*04 & $\mathrm{X}$ & & & Syrian & 0,01 & 1.77 & $\begin{array}{l}\text { (Harfouch-Hammoud } \\
\text { \& Daher, 2008) }\end{array}$ \\
\hline & & $X$ & & Syrian & 0,003 & 0.51 & $\begin{array}{l}\text { (Harfouch-Hammoud } \\
\text { \& Daher, 2008) }\end{array}$ \\
\hline & & & $\mathrm{X}$ & Indonesia. & 0,008 & ND & $\begin{array}{l}\text { (Yuliwulandari } \\
\text { et al., 2010) }\end{array}$ \\
\hline DRB1*1202 & & & $\mathrm{X}$ & Indonesia. & 0.0008 & 0.32 & $\begin{array}{l}\text { (Yuliwulandari } \\
\text { et al., 2010) }\end{array}$ \\
\hline & & $X$ & & Polish & $<0.001$ & 0.04 & $\begin{array}{l}\text { (Dubaniewicz } \\
\text { et al., 2000) }\end{array}$ \\
\hline DRB1*1302 & $X$ & & & $\begin{array}{l}\text { South } \\
\text { Africa }\end{array}$ & $<0,001$ & 5.05 & $\begin{array}{l}\text { (Lombard } \\
\text { et al., 2006) }\end{array}$ \\
\hline DRB1*07 & $X$ & & & Iranian & 0.025 & 2.7 & $\begin{array}{l}\text { (Amirzargar } \\
\text { et al., 2004) }\end{array}$ \\
\hline DRB1*0803 & & & $X$ & Korean & 0.00009 & 5.31 & $\begin{array}{l}\text { (Kim } \\
\text { et al., 2005) }\end{array}$ \\
\hline DQA1*0301 & & $X$ & & Iranian & 0.033 & 0.25 & $\begin{array}{l}\text { (Amirzargar } \\
\text { et al., 2004) }\end{array}$ \\
\hline DQA1*0601 & & $\mathrm{X}$ & & Thailandaise & 0.02 & ND & $\begin{array}{l}\text { (Vejbaesya } \\
\text { et al., 2002) }\end{array}$ \\
\hline DQB1*0301 & & $\mathrm{X}$ & & Thailandaise & 0.01 & ND & $\begin{array}{l}\text { (Vejbaesya } \\
\text { et al., 2002) }\end{array}$ \\
\hline
\end{tabular}




\begin{tabular}{|c|c|c|c|c|c|c|c|}
\hline \multirow[t]{2}{*}{ Candidate allele } & \multicolumn{3}{|c|}{$\begin{array}{l}\text { Genetic polymorphisms } \\
\text { association }\end{array}$} & \multirow[t]{2}{*}{ Population } & \multirow{2}{*}{ P-value } & \multirow{2}{*}{ OR } & \multirow[t]{2}{*}{ References } \\
\hline & Positive & Negative $^{\mathrm{I}}$ & $\begin{array}{l}\text { Recurrent } \\
\text { disease }\end{array}$ & & & & \\
\hline DQB1*0502 & \multicolumn{3}{|l|}{$X$} & Thailandaise & 0.01 & 2.06 & $\begin{array}{l}\text { (Vejbaesya } \\
\text { et al., 2002) }\end{array}$ \\
\hline \multirow[t]{2}{*}{ DQB1*0601 } & \multicolumn{3}{|l|}{$X$} & Indian & 0.008 & 2.32 & $\begin{array}{l}\text { (Ravi kumar } \\
\text { et al., 1999) }\end{array}$ \\
\hline & & & $X$ & Korean & 0.00003 & 5.45 & $\begin{array}{l}\text { (Kim } \\
\text { et al., 2005) }\end{array}$ \\
\hline
\end{tabular}

Table 1. Genetic associations of important MHC gene variants with the susceptibility or resistance to tuberculosis and with disease recurrence. (OR: Odds ratio, ND: no Data)

Additionally, certain alleles like DRB1*11 and DRB1*13 are in contrast associated with protection against PTB (Harfouch-Hammoud \& Daher 2008; Dubaniewicz et al., 2000). This conflicting results reported in theses studies could be due to the positive linkage disequilibrium (LD) observed between MHC class II alleles. DRB1*11-DQB1*03 haplotype was found in positive LD in controls polish patients (Dubaniewicz et al., 2005). In this case, DRB1*03 itself but not DRB1*11 may be linked to the resistance to TB. The hypothesis of the presence of other alleles in LD with DRB1*11-DQB1*03 haplotype is not excluded.

However, even if there are few studies reported in the literature concerning the impact of MHC class I polymorphism on the TB development, it seems likely that some MHC class I alleles are associated with PTB disease, as HLA-A1, HLA-B51, HLA-Cw6 and HLA-Cw7 in Indians (Balamurugan et al., 2004; Vijaya Lakshmi et al., 2006) and HLA-B¹802 and HLA$B^{*} 4001$ in Indonesians (Yuliwulandari et al., 2010). Analysis of these results and others showed that HLA-B alleles may play the main role in PTB development comparing to the other alleles of MHC class I. HLA-B gene is the most polymorphic gene within the human MHC and the fundamental genetic variation occurs within exon 2 and exon 3, known by its determinant function during the presentation of antigenic peptide step. As cited above 2271 alleles of HLA-B are identified to date. In recent cellular immunological study, using IFN-g ELISPOT and following stimulation of $\mathrm{T}$ cell clones with specific Mtb synthetic peptide arrays, Lewinsohn and his colleagues have demonstrated that the immunodominant TB CD8 antigens was preferentially restricted by HLA-B (Lewinsohn et al., 2007). In the same way, it has been reported that the majority of epitope-specific CD8 T cells are HLA-B alleles restricted in patients with PTB and in addition these alleles found fast off-rates in peptide binding (Weichold et al., 2007).

\section{Reverse Immunogenetic and TB diagnosis test development}

For several years biologists used direct smear microscopy and culture for active TB diagnosis. But, until now the gold standard test remains the culture isolation of $\mathrm{Mtb}$ and it is the only test that confirms the diagnosis of TB disease. The control of the disease depends absolutely on early identification and treatment of active cases. However, direct microscopic examination as well as the culture doesn't have an adequate sensitivity and specificity, $20 \%$ and $80 \%$ for the first test and $60 \%$ and $99 \%$ for the second. For this reason, many teams interested in this topic have tried to improve these two parameters in bacteriological, 
immunological and molecular biology techniques. At immunological levels, numerous studies have been reported on the cellular and humoral immunology field a significant improvement for the diagnosis of TB have been described (Seghrouchni et al., 2009; Panigada et al., 2002, Zhang et al., 2010). Unfortunately, none of the immunological methods reported in these studies was able to discriminate between active TB and latent TB infection. The use of Elispot technique and also the specific Mtb antigen have certainly played a good progress to resolve this problem. Among the panel of immunological technology used and the most relevant approach applied in this context is the reverse immunogenetic technique, based on in-silico identification peptide. This method allows the scientific community to better investigate the antigenic peptides that are presented by the relevant MHC molecules. Furthermore, this strategy offers the possibility to identify the specific $\mathrm{T}$ lymphocyte epitopes from living cells and provides a precious help for the development of vaccine candidates. This approach has been elegantly used to identify a specific $\mathrm{T}$ lymphocyte epitopes antigen in cancer (Liu et al., 2011; Imai et al., 2011) and in infectious disease (Kawashima et al., 2008; Hossain et al., 2003; Sobao et al., 2001; Seghrouchni et al., 2009; Wang et al., 2010). Various studies have been reported regarding the use of this strategy in TB disease. All immunological investigations are focused to produce a specific and synthetic peptide of Mtb in order to improve the sensitivity and the specificity of the diagnosis Kits. Several MTB-specific antigenic peptides demonstrated their potential application for TB diagnosis, (Ravn et al., 1999; Arend et al., 2002, Seghrouchni et al., 2009; Panigada et al., 2002, Zhang et al., 2010).

Both MHC class I and class II-restricted responses against Mtb are explored in this context with major importance for MHC class II. This importance takes its consideration regarding the roles played by CD4 T Lymphocytes in developing candidate vaccine for TB. In fact, Numerous $\mathrm{Mtb}$ specific antigens for $\mathrm{CD} 4+\mathrm{T}$ lymphocytes have been identified and characterized up till now. We have previously identified Mtb specific peptide, selected from RD1 genomic region (Mahairas et al., 1996) and from proteins expressed during MTB growth in human macrophage (Cappelli et al., 2006; Mariani et al., 2000), and which are predicted to bind HLA-DR alleles (Seghrouchni et al., 2009. Baassi et al., 2009). IFN- $\gamma$ ELISPOT after stimulation by Mtb selected peptide of peripheral blood mononuclear cells, extracted from TB patients and Healthy controls, have revealed an excellent result. In fact, using statistical algorithms we have identified a pool of specific Mtb immunodominant B and $\mathrm{T}$ cell epitopes, able to discriminate between active TB patients, tuberculin skin test positive (Mtb exposed subjects) and tuberculin skin test negative controls. A similar study has been reported recently using bioinformatic tools (chaitra et al., 2008). In fact, the authors of this work have designed some HLA class I binding epitopes of the PE (Pro-Glu) and PPE (Pro-Pro-Glu) proteins of Mtb, which are coded by Rv1818c, Rv3812 and Rv3018c genes, and have observed a significant difference in the responsiveness between healthy subjects and TB patients.

Likewise, other investigations have been reported concerning MHC class I and in-silico identification peptides. By means of appropriate bioinformatic tools several peptides are identified and could be used to improve both TB diagnosis and vaccine development. More recently, using HLA-peptide tetramers derived from Mtb peptides predicted to bind to HLA-A*0201, Tang and his colleagues have found a very interesting Mtb epitopes activating polyfunctional CD8+ T cells in human TB (Tang et al., 2011). Moreover, some specific 
peptides to CD8 T Lymphocytes as HLA-B*35-restricted CD8(+) T-cell epitope in Mtb Rv2903c (Klein et al., 2002), HLA-A*0201-restricted T-cell epitope in the MPT51 protein (Aoshi et al., 2008) and HLA-B*35-restricted CD8 T cell epitopes in the antigen 85 (aa 204212) WPTLIGLAM (Klein et al., 2001), were demonstrated to have a potential positive effect on Mtb -infected macrophages and produce significant level of gamma interferon and tumor necrosis factor alpha.

\section{Conclusion}

Taking all these data together reported in this review we can conclude that: MHC polymorphism and immunogenetic reverse studies offer a precious help at different level, in the identification of susceptibility/resistance genes or cluster of genes that are involved in the TB disease, and in the characterisation of a specific and relevant Mtb $\mathrm{T}$ lymphocyte epitopes for diagnosis improvement and vaccine development. The advancement of bioinformatic tools and immunological technologies could undoubtedly contribute to understand well the immunogenetic of $\mathrm{TB}$, and consequently to improve the quality and the reliability (sensitivity/specificity) of immunological diagnosis Kits.

\section{References}

Acharya S, Shukla S, Mahajan SN, Diwan SK. (2010). Molecular mimicry in human diseasesphenomena or epiphenomena?. J Assoc Physicians India, Vol.58, (Mar), pp.163-8, ISSN 0004-5772

Amirzargar AA, Yalda A, Hajabolbaghi M, Khosravi F, Jabbari H, Rezaei N, Niknam MH, Ansari B, Moradi B, Nikbin. (2004). The association of HLA-DRB, DQA1, DQB1 alleles and haplotype frequency in Iranian patients with pulmonary tuberculosis. Int J Tuberc Lung Dis, Vol.8 No.8 (Aug), pp.1017-1021, ISSN 1027-3719

Aoshi T, Nagata T, Suzuki M, Uchijima M, Hashimoto D, Rafiei A, Suda T, Chida K, Koide Y. (2008). Identification of an HLA-A*0201-restricted T-cell epitope on the MPT51 protein, a major secreted protein derived from Mycobacterium tuberculosis, by MPT51 overlapping peptide screening. Infect Immun, Vol.76, No.4, (Apr), pp. 15651571, ISSN 0019-9567

Arend SM, van Meijgaarden KE, de Boer K, de Palou EC, van Soolingen D, Ottenhoff TH, van Dissel JT. (2002). Tuberculin skin testing and in vitro T cell responses to ESAT6 and culture filtrate protein 10 after infection with Mycobacterium marinum or M. kansasii. J Infect Dis, Vol.186, No.12 (Dec 15), pp. 1797-1807, ISSN 0022-1899

Baassi L, Sadki K, Seghrouchni F, Contini S, Cherki W, Nagelkerke N, Benjouad A, Saltini C, Colizzi V, El Aouad R, Amicosante M. (2009). Evaluation of a multi-antigen test based on B-cell epitope peptides for the serodiagnosis of pulmonary tuberculosis. Int J Tuberc Lung Dis,Vol.13, No.7, (Jul), pp. 848-854, ISSN 1027-3719

Balamurugan A, Sharma SK, Mehra NK. (2004). Human leukocyte antigen class I supertypes influence susceptibility and severity of tuberculosis. J Infect Dis, Vo.189, No.5 (Mar 1), pp.805-811, ISSN 0022-1899

Bjorkman, P. J., Saper, M. A., Samraoui, B., Bennett, W. S., Strominger, J. L., and Wiley, D. C. (1987). The foreign antigen binding site and $\mathrm{T}$ cell recognition regions of class I histocompatibility antigens. Nature, Vol. 329, No. 6139, pp. 512-518, ISSN, 0028-0836 
Brahmajothi V, Pitchappan RM, Kakkanaiah VN, Sashidhar M, Rajaram K, Ramu S, Palanimurugan K, Paramasivan CN, Prabhakar R. (1991). Association of pulmonary tuberculosis and HLA in south India. Tubercle, Vol.72, No.2, (Jun), pp. 123-132, ISSN 0041-3879

Cappelli G, Volpe E, Grassi M, Liseo B, Colizzi V, Mariani F. (2006). Profiling of Mycobacterium tuberculosis gene expression changes during human macrophages infection: up-regulation of the alternative sigma factor $G$, of a group of transcriptional regulators and of proteins with no known function. Res Microbiol, Vol.157, pp. 445-455, ISSN 0923-2508

Chaitra MG, Shaila MS, Nayak R. (2008). Detection of interferon gamma-secreting CD8+ T lymphocytes in humans specific for three PE/PPE proteins of Mycobacterium tuberculosis. Microbes Infect, Vol.10, No.8, (Jul), pp. 858-867, ISSN 1286-4579

Da Silva SA, Mazini PS, Reis PG, Sell AM, Tsuneto LT, Peixoto PR and Visentainer JEL. (2009). HLA-DR and HLA-DQ alleles in patients from the south of Brazil: markers for leprosy susceptibility and resistance. BMC Infectious Diseases, Vol.9, No.134. , pp. 1-7, ISSN 1471-2334

De Castro JA. (2009). HLA-B27-bound peptide repertoires: their nature, origin and pathogenetic relevance. Adv Exp Med Biol; Vol.649, pp.196-209, ISSN 0004-5772

Duarte R, Carvalho C, Pereira C, Bettencourt A, Carvalho A, Villar M, Domingos A, Barros H, Marques J, Pinho Costa P, Mendonça D, Martins B. (2011). HLA class II alleles as markers of tuberculosis susceptibility and resistance. Rev Port Pneumol, Vol.17, No.1, (Jan), pp. 15-19, ISSN 0873-2159

Dubaniewicz A, Lewko B, Moszkowska G, Zamorska B, Stepinski J. (2000). Molecular subtypes of the HLA-DR antigens in pulmonary tuberculosis. Int J Infect Dis, Vol.4, No.3, pp.129-133, ISSN 1201-9712

Dubaniewicz A, Moszkowska G, Szczerkowska Z. (2005). Frequency of DRB1-DQB1 twolocus haplotypes in tuberculosis: Preliminary report. Tuberculosis, Vol. 85, No. 4, (Jul), pp. 259-267, ISSN 1472-9792

Garrett, T. P., Saper, M. A., Bjorkman, P. J., Strominger, J. L., and Wiley, D. C. (1989). Specificity pockets for the side chains of peptide antigens in HLA-Aw68. Nature, Vol. 342, No. 6250, pp. 692-696, ISSN 0028-0836

Geluk A, van Meijgaarden KE, Franken KL, Drijfhout JW, D'Souza S, Necker A, Huygen K, Ottenhoff TH. (2000). Identification of major epitopes of Mycobacterium tuberculosis AG85B that are recognized by HLA-A*0201-restricted CD8+ T cells in HLA-transgenic mice and humans. J Immunol, Vol. 165, No.11, (Dec 1), pp. 64636471, ISSN 0022-1767

Harfouch-Hammoud EI, Daher NA. (2008) Susceptibility to and severity of tuberculosis is genetically controlled by human leukocyte antigens. Saudi Med J, Vol.29, No.11, pp. 1625-1629, ISSN 0379-5284

Hill AV. Aspects of genetic susceptibility to human infectious diseases. (2006). Annu Rev Genet, Vol. 40, pp. 469-486, ISSN, 0066-4197

Hossain MS, Tomiyama H, Inagawa T, Ida S, Oka S, Takiguchi M. (2003). Identification and characterization of HLA-A*3303-restricted, HIV type 1 Pol- and Gag-derived cytotoxic T cell epitopes. AIDS Res Hum Retroviruses, Vol.19, No.6, (Jun), pp. 503510, ISSN 0889-2229 
Imai K, Hirata S, Irie A, Senju S, Ikuta Y, Yokomine K, Harao M, Inoue M, Tomita Y, Tsunoda T, Nakagawa H, Nakamura Y, Baba H, Nishimura Y. (2011). Identification of HLA-A2-restricted CTL epitopes of a novel tumour-associated antigen, KIF20A, overexpressed in pancreatic cancer. Br J Cancer, Vol.104, No.2, (Jan), pp. 300-307, ISSN 0007-0920

Jepson A, Fowler A, Banya W, Singh M, Bennett S, Whittle H, Hill AV. (2001). Genetic regulation of acquired immune responses to antigens of Mycobacterium tuberculosis: a study of twins in West Africa. Infect Immun, Vol.69, pp. 3989-3994, ISSN 0019-9567

Kamath AB, Alt J, Debbabi H, Taylor C, Behar SM. (2004). The major histocompatibility complex haplotype affects $\mathrm{T}$-cell recognition of mycobacterial antigens but not resistance to Mycobacterium tuberculosis in C3H mice. Infect Immun, Vol.72, No.12, (Dec), pp. 6790-6798, ISSN 0019-9567

Kawashima Y, Satoh M, Oka S, Shirasaka T, Takiguchi M. (2008). Different immunodominance of HIV-1-specific CTL epitopes among three subtypes of HLAA*26 associated with slow progression to AIDS. Biochem Biophys Res Commun, Vol.366, No.3, (Feb 15), pp. 612-616, ISSN 0006-291X

Kettaneh A, Seng L, Tiev KP, Tolédano C, Fabre B, Cabane J. (2006). Human leukocyte antigens and susceptibility to tuberculosis: a meta-analysis of case-control studies. Int J Tuberc Lung Dis, Vol.10, No.7, (Jul), pp. 717-25, ISSN 1027-3719

Kim HS, Park MH, Song EY, Park H, Kwon SY, Han SK, Shim YS. (2005). Association of HLA-DR and HLA-DQ genes with susceptibility to pulmonary tuberculosis in Koreans: preliminary evidence of associations with drug resistance, disease severity, and disease recurrence. Hum Immunol, Vol.66, No.10, (Oct), pp. 1074-1081, ISSN 0198-8859

Klein MR, Hammond AS, Smith SM, Jaye A, Lukey PT, McAdam KP. (2002). HLA-B*35restricted CD8(+)-T-cell epitope in Mycobacterium tuberculosis Rv2903c. Infect Immun, Vol.70, No.2, (Feb), pp. 981-984, ISSN 0019-5522

Klein MR, Smith SM, Hammond AS, Ogg GS, King AS, Vekemans J, Jaye A, Lukey PT, McAdam KP. (2001). HLA-B*35-restricted CD8 T cell epitopes in the antigen 85 complex of Mycobacterium tuberculosis. J Infect Dis, Vo.183, No.6, (Mar), pp. 928934, ISSN 0022-1899

Lalvani A, Brookes R, Wilkinson RJ, Malin AS, Pathan AA, Andersen P, Dockrell H, Pasvol G, Hill AV. (1998). Human cytolytic and interferon gamma-secreting CD8+ T lymphocytes specific for Mycobacterium tuberculosis. Proc Natl Acad Sci U $S$ A, Vol.95, No.1, (Jan 6), pp. 270-275, ISSN, 0027-8484

Lewinsohn DA, Winata E, Swarbrick GM, Tanner KE, Cook MS, Null MD, Cansler ME, Sette A, Sidney J, Lewinsohn DM. (2007). Immunodominant tuberculosis CD8 antigens preferentially restricted by HLA-B. PLoS Pathog, Vol.3, No.9, (Sep 21), pp.1240-1249, ISSN 1553-7366

Li, Y., Depontieu, F.R., Sidney, J., Salay, T.M., Engelhard, V.H., Hunt, D.F., Sette, A., Topalian, S.L., Mariuzza, R.A. (2010). Structural basis for the presentation of tumorassociated MHC class II-restricted phosphopeptides to CD4+ T cells. J.Mol.Biol, Vol.399, pp. 596-603, ISSN 0022-2836 
Liu W, Zhai M, Wu Z, Qi Y, Wu Y, Dai C, Sun M, Li L, Gao Y. (2011). Identification of a novel HLA-A2-restricted cytotoxic T lymphocyte epitope from cancer-testis antigen PLAC1 in breast cancer. Amino Acids, Vol. 28, (Jun), ISSN 0939-4454

Lombard Z, Dalton DL, Venter PA, Williams RC, Bornman L. (2006). Association of HLA$\mathrm{DR},-\mathrm{DQ}$, and vitamin $\mathrm{D}$ receptor alleles and haplotypes with tuberculosis in the Venda of South Africa. Hum Immuno, Vol.67, No.8, (Aug), pp. 643-654. ISSN 01988859

Maartens G, Wilkinson RJ. Tuberculosis. (2007). Lancet, Vol.370, pp. 2030-2043. ISSN 01406736

Madden, D. R., Gorga, J. C., Strominger, J. L., and Wiley, D. C. (1991). The structure of HLAB27 reveals nonamer self-peptides bound in an extended conformation. Nature. Vol.353, No.6342, pp. 321-325, ISSN 0028-0836

Mahairas GG, Sabo PJ, Hickey MJ, Singh DC, Stover CK. (1996). Molecular analysis of genetic differences between Mycobacterium bovis BCG and virulent M. bovis. J Bacterio, Vol.178, pp. 1274-1282, ISSN 0021-9193

Malissen, M., Malissen, B., and Jordan, B. R. (1982). Exon/intron organization and complete nucleotide sequence of an HLA gene. Proc Natl Acad Sci U S A, Vol.79, No.3, pp. 893-897, ISSN 0027-8424

Mariani F, Cappelli G, Riccardi G, Colizzi V. (2000). Mycobacterium tuberculosis H37Rv comparative gene-expression analysis in synthetic medium and human macrophage. Gene, Vol.253, pp. 281-291, ISSN 0378-1119

Matsumura, M., Fremont, D. H., Peterson, P. A., and Wilson, I. A. (1992). Emerging principles for the recognition of peptide antigens by MHC class I molecules. Science, 257(5072), 927-934, ISSN 0036-8075

Mohagheghpour N, Gammon D, Kawamura LM, van Vollenhoven A, Benike CJ, Engleman EG. (1998). CTL response to Mycobacterium tuberculosis: identification of an immunogenic epitope in the 19-kDa lipoprotein. J Immunol, Vol.161, No.5, (Sep 1), pp. 2400-2406, ISSN 0022-1767

Moss D J, Khanna R. (1999). Major histocompatibility complex: from genes to function. Immunol Today; Vol.20, pp. 165-167, ISSN 0167-5699

Panigada M, Sturniolo T, Besozzi G, Boccieri MG, Sinigaglia F, Grassi GG, Grassi F. (2002). Identification of a promiscuous T-cell epitope in Mycobacterium tuberculosis Mce proteins. Infect Immun, Vol.70, No.1, (Jan), pp. 79-85

Rajeswari DN, Selvaraj P, Raghavan S, Jawahar MS, Narayanan PR. (2007). Influence of HLA-DR2 on perforin-positive cells in pulmonary tuberculosis. Int J Immunogenet, Vol.34. No.5, (Oct), pp. 379-384, ISSN 1744-3121

Ravikumar M, Dheenadhayalan V, Rajaram K, Lakshmi SS, Kumaran PP, Paramasivan CN, Balakrishnan K, Pitchappan RM. (1999). Associations of HLA-DRB1, DQB1 and DPB1 alleles with pulmonary tuberculosis in south India. Tuber Lung Dis, Vol.79, No.5, pp. 309-317, ISSN 0962-8479

Ravn P, Demissie A, Eguale T, Wondwosson H, Lein D, Amoudy HA, Mustafa AS, Jensen AK, Holm A, Rosenkrands I, Oftung F, Olobo J, von Reyn F, Andersen P. (1999). Human T cell responses to the ESAT-6 antigen from Mycobacterium tuberculosis. J Infect Dis, Vol.179, No.3, (Mar), pp. 637-645, ISSN .0022-1899

Robinson J, Waller MJ, Parham P, de Groot N, Bontrop R, Kennedy LJ, Stoehr P, Marsh SG. (2003). IMGT/HLA and IMGT/MHC: sequence databases for the study of the 
major histocompatibility complex. Nucleic Acids Res. Vol.31, No.1, (Jan 1), pp. 311314, ISSN 0305-1048

Seghrouchni F, Contini S, Markova R, Drenska R, Sadki K, Baassi L, Todorova Y, Terzieva V, Bocchino M, Cappelli G, Altieri AM, Alma MG, Benjouad A, Mariani F, Petrunov B, Colizzi V, El Aouad R, Saltini C, Amicosante M. (2009). Design of immunogenic peptides from Mycobacterium tuberculosis genes expressed during macrophage infection. Tuberculosis, Vol.89, No.3, (May), pp. 210-217, ISSN 1472-9792

Shi GL, Hu XL, Yang L, Rong CL, Guo YL, Song CX. (2011). Association of HLA-DRB alleles and pulmonary tuberculosis in North Chinese patients. Genet Mol Res, Vol.10, No.3, (Jul), pp. 1331-1336, ISSN 1676-5680

Smith SM, Dockrell HM. (2000). Role of CD8 T cells in mycobacterial infections. Immunol Cell Biol, Vol.78, No.4, (Aug), pp. 325-333, ISSN 0818-9641

Sobao Y, Sugi K, Tomiyama H, Saito S, Fujiyama S, Morimoto M, Hasuike S, Tsubouchi H, Tanaka K, Takiguch M. (2001). Identification of hepatitis B virus-specific CTL epitopes presented by HLA-A*2402, the most common HLA class I allele in East Asia. J Hepatol, Vol.34, No.6, (Jun); pp. 922-999, ISSN 0168-8278

Sriram U, Selvaraj P, Kurian SM, Reetha AM, Narayanan PR. (2001). HLA-DR2 subtypes \& immune responses in pulmonary tuberculosis. Indian J. Med Res, Vol.113, pp. 117124, ISSN 0971-5916

Tang ST, van Meijgaarden KE, Caccamo N, Guggino G, Klein MR, van Weeren P, Kazi F, Stryhn A, Zaigler A, Sahin U, Buus S, Dieli F, Lund O, Ottenhoff TH. (2011). Genome-based in silico identification of new Mycobacterium tuberculosis antigens activating polyfunctional CD8+ T cells in human tuberculosis. J Immunol, Vol.186, No.2, (Jan 15), pp. 1068-1080, ISSN 0022-1767

Vannberg FO, Chapman SJ, Hill AV. (2011). Human genetic susceptibility to intracellular pathogens. Immunol Rev, Vol.240, No.1, (Mar), pp. 105-116, ISSN 0105-2896

Vejbaesya S, Chierakul N, Luangtrakool K, Srinak D, Stephens HA. (2002). Associations of HLA class II alleles with pulmonary tuberculosis in Thais. Eur J Immunogenet, Vol.29, No.5, (Oct), pp. 431-434, ISSN 0960-7420

Vijaya Lakshmi V, Rakh SS, Anu Radha B, Hari Sai Priya V, Pantula V, Jasti S, Suman Latha G, Murthy KJ. (2006). Role of HLA-B51 and HLA-B52 in susceptibility to pulmonary tuberculosis. Infect Genet Evol, Vol.6, No.6, (Nov), pp. 436-439, ISSN $1567-1348$

Wang LX, Nagata T, Tsujimura K, Uchijima M, Seto S, Koide Y. (2010). Identification of HLA-DR4-restricted T-cell epitope on MPT51 protein, a major secreted protein derived from Mycobacterium tuberculosis using MPT51 overlapping peptides screening and DNA vaccination. Vaccine, Vol.28. No.8, (Feb 23), pp. 2026-2031, ISSN 0264-410X

Weichold FF, Mueller S, Kortsik C, Hitzler WE, Wulf MJ, Hone DM, Sadoff JC, Maeurer MJ. (2007). Impact of MHC class I alleles on the M. tuberculosis antigen-specific CD8+ T-cell response in patients with pulmonary tuberculosis. Genes Immun, Vol.8, No.4, (Jun), pp. 334-343, ISSN 1466-4879

Yee LJ. (2004). Host genetic determinants in hepatitis C virus infection. Genes Immun,Vol.5, pp. 237-245, ISSN 1466-4879

Yim JJ, Selvaraj P. (2010). Genetic susceptibility in tuberculosis. Respirology, Vol.15, No.2, (Feb), pp. 241-256, ISSN 1323-7799 
Yuliwulandari R, Sachrowardi Q, Nakajima H, Kashiwase K, Hirayasu K, Mabuchi A, Sofro AS, Tokunaga K. (2010). Association of HLA-A, -B, and -DRB1 with pulmonary tuberculosis in western Javanese Indonesia. Hum Immunol, Vol.71, No.7, (Jul), pp. 697-701, ISSN 0198-8859

Zhang S, Shao L, Mo L, Chen J, Wang F, Meng C, Zhong M, Qiu L, Wu M, Weng X, Zhang W. (2010). Evaluation of gamma interferon release assays using Mycobacterium tuberculosis antigens for diagnosis of latent and active tuberculosis in Mycobacterium bovis BCG-vaccinated populations. Clin Vaccine Immunol, Vol.17, No.12, (Dec), pp. 1985-1990, ISSN 1556-6811 


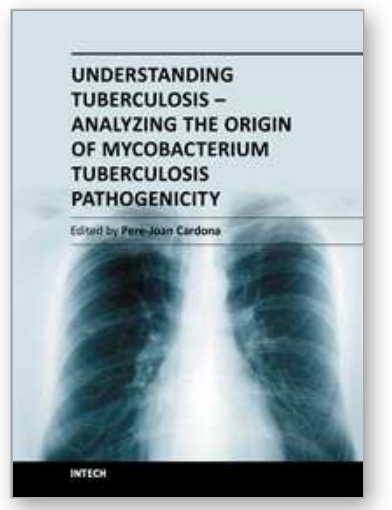

\section{Understanding Tuberculosis - Analyzing the Origin of Mycobacterium Tuberculosis Pathogenicity \\ Edited by Dr. Pere-Joan Cardona}

ISBN 978-953-307-942-4

Hard cover, 560 pages

Publisher InTech

Published online 24, February, 2012

Published in print edition February, 2012

Mycobacterium tuberculosis in an attempt to understand the extent to which the bacilli has adapted itself to the host and to its final target. On the other hand, there is a section in which other specialists discuss how to manipulate this immune response to obtain innovative prophylactic and therapeutic approaches to truncate the intimal co-evolution between Mycobacterium tuberculosis and the Homo sapiens.

\section{How to reference}

In order to correctly reference this scholarly work, feel free to copy and paste the following:

Khalid Sadki, Youssef Bakri, M'Hamed Tijane and Saaid Amzazi (2012). MHC Polymorphism and Tuberculosis Disease, Understanding Tuberculosis - Analyzing the Origin of Mycobacterium Tuberculosis Pathogenicity, Dr. Pere-Joan Cardona (Ed.), ISBN: 978-953-307-942-4, InTech, Available from:

http://www.intechopen.com/books/understanding-tuberculosis-analyzing-the-origin-of-mycobacteriumtuberculosis-pathogenicity/mhc-polymorphism-and-tuberculosis-disease

\section{INTECH}

open science | open minds

\section{InTech Europe}

University Campus STeP Ri

Slavka Krautzeka 83/A

51000 Rijeka, Croatia

Phone: +385 (51) 770447

Fax: +385 (51) 686166

www.intechopen.com

\section{InTech China}

Unit 405, Office Block, Hotel Equatorial Shanghai

No.65, Yan An Road (West), Shanghai, 200040, China

中国上海市延安西路65号上海国际贵都大饭店办公楼 405 单元

Phone: +86-21-62489820

Fax: $+86-21-62489821$ 
(C) 2012 The Author(s). Licensee IntechOpen. This is an open access article distributed under the terms of the Creative Commons Attribution 3.0 License, which permits unrestricted use, distribution, and reproduction in any medium, provided the original work is properly cited. 